\title{
SENDIKALARIN MAHIYETI
}

GİRIȘ. I. BÖLÜM : GENEL OLARAK TÜZEL KIȘILER. 1 - Tanım. 2 - Tüzel Kişilerin Çeşitleri. A - Kamu Hukuku Tüzel. Kişileri. a - Kamu Idareleri. b - Kamu Kurumları. B - Özel Hukuk Tüzel Kişileri. a - Kazanç Gayesi Güden Tüzel Kişiler. b - Kazanç Gayesi Gütmeyen Tüzel Kişiler. aa - Dernekler. bb-Vakıflar. II. BÖLÜM : GENEL OLARAK SENDIKALAR.1 - Sendikalarn Hukukî Düzenleme İçindeki Yerleri. A - Tanım. B - Sendikaların Bir Tüzel Kişi Olarak Hukukî Mahiyeti. a - Kamu Hukuku Tüzel Kişileri Açısından. b-Özel Hukuk Tüzel Kişileri Açısından. aaȘirketler Açısından. bb-Dernekler Açısından. 2-Sendikaların Hukukî Düzenleme Dışında "Sosyal Gerçek»likteki Yerleri. A Menfaat Grubu, Baskı Grubu Ayrımı. B - Bir Baskı Grubu Olarak Sendikalar. SONUÇ

\section{GIRIŞ}

Bu çalışmamıza konu olan sendikalar, dünya tarihinde küçümsenemiyecek bir geçmișe sahiptir. Bir toplumda meslekî alanda örgütlenme hakkının tanınması, çalışanlarla çalıştıranların araların. daki ilișkilerin düzenlenmesi demek olan sendika hukukunun doğg. ması, belirli ekonomik ve sosyal koşulların gerçekleşmesine bağgldır. Tarımdan sanayileşmeye geçiş ve ekonominin belli bir düzeye ulaşması sonucunda ortaya işçi ve işveren sınıflanı çıkmıștır. Çalışan ve yaşayabilmek için emeğinin gelirinden başka bir imkânı bu. lunmayan kimse işveren karşısında güçsìz durumdadır. Ucret kendisine işveren tarafindan verilmektedir. Bunu kabul etmeyip çaliş. madıği takdirde aç kalır. Bu nedenle emek piyasasında çalışanlar arasında sürekli bir rekabet vardır. Ișçi ve ișverenler arasındaki 
ilişkiler tüm olarak serbest bırakıldığı takdirde işveren, örgütlenmemiş işçi arasındaki rekabetten ve kendisinin ekonomik güçliilüğünden yararlanarak en düşük ücreti verme yoluna gidecektir. $\mathrm{Bu}$ durumdan tüm ülkenin ekonomik ve sosyal bünyesi zarara uğrayacaktır. Iște, çalışanların organize olmaları ve sendikaların ku. rulmalan bu zorunluktan doğmuştur.

Bizde sendikalarnn oluşumu yakın bir geçmişe dayanır. Os. manlı Imparatorluğu tüm olarak tarımsal bir ekonomiye dayandığından ve sanayileşme hareketi bir ką̧ imtiyazlı yabancı kuruluş dışında var olmadığından, batıda olduğu gibi işçi ve ișveren ilişkileri oluşamamıș, hürriyetsizlik nedeniyle de sosyal ilişkilere memleketimiz sahne olamamıştır. Kurtuluş Savaşı biter bitmez çalışanı küçümsiyen düşünce yrkılıp, yerine çạlıșmayı en büyük șeref sayan yeni bir dünya görüşü getirilmiștir.

Cumhuriyetin ilânından sonra, Türkiye'nin sanayileşmesi için sarfedilen emekler kamu iktisadî teșebbüsleri șeklinde kendini göstermiş, Sümerbank, Etibank, gibi kurumlar batı ölçüsünde bü. yük işletmeler kurmuşlar ve bu suretle ülkemizde bir iş̧̧i ve işveren sorunu ve buna bağh olarak işçi ve ișveren ilișkilerini düzenleyen normların konulması zorunluğu ortaya çıkmıștır.

Devlet eliyle kurulan her fabrika ve ișletmenin yanında yıkanma ve dinlenme yerleri, yemekhaneler, hastahaneler, okullar yapılmış, yine bu işletmelerde çalışanlar için hastalık ve ölüm yardımı sandıklanı kurularak sosyal sigortanın ilk çekirdeği oluşturulmuştur.

1936 yllında 3008 Saylı İ Kanunu çıkarılmış ve bu kanun ile ülkemizde iş hukukunun temeli de atılmıştrr. Bu kanunun uygulanması için o zamanki Iktisat Vekâletinde bir Iṣ Dairesi kurulmuş. tur.

tkinci Dünya Savaşı sırasında $\mathbf{4 7 7 2}$ Saylı als Kazalan ve Meslek Hastalıkları ve Analık Sigortaları» Kanunu kabul edilmiștir. 4792 Sayıl Kanun ile "Ișçi Sigortaları Kurumu» ve ardindan 4837 Sayllı Kanunla da *Iș ve Isş̧i Bulma Kurumu» kurulmuştur.

Bundan sonra, çalıșma hayatımın düzenlenmesi, çalışanların yaşama standardının yükseltilmesi, memlekette çalışma gücünün ve refahın arttırılması gibi sorunların çözülüp yürütülmesi işlerinin hükümet kadrosu içinde sorumlu bir bakanlığa görev olarak verilmesi gereği kendini göstermiştir. Bunu sağlamak amacryla 4841 Sayılı Kanun ile Çałışma Bakanlı̆̆ı kurulmuştur. 
Nihayet, 20.2.1947 tarihinde «Işçi ve İşveren Sendikaları ve Sendika Birlikleri» hakkındaki 5018 Sayll Kanun kabul edilmiştir.

Giderek, çeşitli yetkilerle donatılan sendikalar, 1961 T.C. Anayasasmın 46. maddesiyle anayasal güvenceye de kavușturul, muş ve bu maddenin ışı̆̆ı altında 274 Sayılı Sendikalar Kanunu hazırlanarak yürürliuğe konulmuştur.

Sendikalar Türk Siyasal hayatında zaman zaman ön plâna geçmiş ve siyasal karar merkezlerine etkide bulunan rollere sahip olmuşlardur.

Íki bölüimden ibaret olan çalışmamızın birinci bölümünde tüzel kişilerin tanımına ve çeşitlerine yer verilmiş, ikinci bölümünde ise, sendikaların tanım ve mahiyetinin incelenmesine gayret gösterilmiștir.

Çalışmamızın ağırlı̆ğt, sendikaların hukukî düzenleme içindeki yerleri noktasında toplanmıs bulunmaktadır. Sendikaların faaliyetlerini incelemeye derinlemesine girilmemiş, siyasal hayattaki rollerinin baski grubu $\mathrm{mu}$, menfaat grubu mu olduğunu saptayabilmek için bazı eylemleri üzerinde durmakla yetinilmiştir.

\section{I. $B \not ̛ \mathrm{~L} \circlearrowright \mathrm{M}$}

\section{GENEL, OLARAK TƯZEL KIŞILER}

\section{1 - Tanim :}

Hak ve fiil ehliyeti iktidarı yalntz insanlarn tekelinde degildir. Insanların yanıbaşında, hukuk, bu iktidarı bazı kişi ve mal topluluklarına da tanımıștır. Iște hukukun insanlar gibi hak ve fiil ehliyetine sahip olduklarını kabul ederek, hukuk duinyasında süje olarak tanıdığı bu kiși ve mal toplulukları tüzel kişilerdir.t

Hak süjesi olmak tüzel kişinin niteliğidir. Bu nitelik tüzel kişinin mahyetini açıklamaz. Tüzel kişinin mahiyetini bize tanımı açıklayacaktır.

Tüzel kişiler belirlì bir gayeye hizmet için bağımsız ve devam. 11 olmak üzere örgütlenmiş kişi ve mal topluluklarıdır.

1 Doğanay, Umit : «Hükmî Sahıslar», Ders Notlan, 2. bast., Ist. 1969, Sh. I. 
$\mathrm{Bu}$ tanıma göre herhangi bir kiși veya mal topluluğunun tüzel kiși niteliğini kazanabilmesi için gerekli olan unsurları şu şekilde suralayabiliriz :

a - Gaye :

Bir araya gelen kişiler arasında ortak bir gayenin varlığı gereklidir. Yani birden çok kişi bu gayeye ulaşmak amacıyla birleş. miş olmalı veya mal topluluğu bu gayeye hizmet etmek üzere tahsis edilmiş bulunmalıdur. ${ }^{2}$

Tüzel kişinin bir gaye birliği olmasının sonucu, kurulușta ve kuruluştan sonra tüzel kişi için kendi içinde birbirine karşıt çıkarlar sorununun söz konusu olmamasıdır. ${ }^{3}$

b - Bağımsız bir topluluk oluşturma iradesi :

Ortak gaye etrafında toplanış veya ortak gayeye bir mamelek tahsis ediş, bağımsız olan ve bütün teşkil eden bir topluluğu meydana getirmek amacıyla olmalıdır. Bu şekilde ortaya çıkan topluIuk, kendisini kuranlardan bağimsız bir kişiliğe sahiptir.

c - Tüzel kişi örgütlenmiş. kişi veya mal topluluğudur :

Kişi ve mal toplulukłarının, görev ve yetkileri tespit edilmiş organlara sahip olmasuna örgütlenme denir. Tüzel kişi, maddi varlığı olmayan bir hukuk süjesi olarak, örgütlenmeye muhtaçtır. Çünkü, tüzel kişilerin hukuk dünyasında varlıkları organ dediğimiz örgütleri ile hissedilir ve kabul edilir.4

Bu açıklamalarımızdan sonra, tüzel kişileri "hukuk hayatında haklara ve borçlara ehil ve organları vasitasıyla karar alabilme durumunda olan, sosyal hayatın gereklerinin doğurduğu, belli bir gaye için birleşmiş, inșan ve mal toplulukları" ${ }^{5}$ olarak tanımlayabiliriz.

\section{2-Tüzel Kișilerin Ceşitleri :}

Tüzel kișiler tâbi oldukları hukuk kurallarına göre, kamu hu. kuku tüzel kişileri ve özel hukuk tüzel kişileri olmak üzere ikiye ayrılmaktadırlar. Kamu hukuku tüzel kişileriyle özel hukuk tüzel kişileri arasında esas itibariyle bünye ve yapılıș farkı yoktur. Ara-

\footnotetext{
${ }^{2}$ Akipek, Jale : «Tïnk Medeni Hukukus, C. 1, 2. Cïz., Ank. 1961, Sh. 224.

${ }^{3}$ Doganay Umit : a.g.e., Sh. 3.

4 Doğanay Umit : a.g.e., Sh. 2.

5 Velidedeoğlu, H. Veldet :" "Türk Medeni Hukuku», C. 1, İst. 1960., Sh. 169.
} 
larındaki fark, doğuş, sona eriş, işleyiş biçimleri, çalışma alanları ve tâbi oldukları hukuk kuralları bakımındandır.

\section{A - Kamu Hukuku Tüzel Kisileri :}

Kamu hukuku tüzel kişileri, kaynağını kamu hukukundan alır. Kưuluşları, kendilerini meydana getiren kişilerin jradelerine değil, bir kamu hukuku tasarrufuna dayanır.6 Bunlar kamu otoritesine sahiptirler.

Anayasanin 112. maddesinin 3. fıkrası, kamu tüzel kişiliğinin ancak kanunla veya kanunun açıkca verdiği yetkiye dayanılarak kurulacağını belirtmiş, Medeni Kanunun 52. maddesinin 1. fikrası ise, kamu hukuku tüzel kişilerinin, kamu hukuku kanunlarına tâbi olacağını hükme bağlamıștır.?

Kamu hukuku tüzel kişilerinin öezl hukuk tïzel kişilerinden farklı muameleye tâbi tutulması nedeni, bunların, «kamuya mahsus» olmaları, kamu hizmeti görmeleridir. ${ }^{8}$

Kamu hukuku tüzel kişileri de iki gruba ayrılabilir :

a - Kamu Ídareleri : Belli bir beldede oturan halk topluluğu, kamu idarelerini meydana getirir. Bu topluluğun en büyüğì devlet olup, il ve köy gibi dił̌er kamu idareleri devlet içinde yer almaktadır.'

b - Kamu Kurumları: Bazı kamu hizmetleri kamu idarelerinden ayrılmakta, bağımsız başka bir tüzel kişiye verilmektedir ki, bunlara kamu kurumu denilmektedir. ${ }^{10}$

Bunların yanında bir takım meslek teşekküllerine, kanunla tïzel kișilik kazandırılmıs ve kamu kurumu niteliği verilmiştir.

Bunun nedeni, bu teșekküllerin görevi arasında, birer kamu hizmeti teșkil eden faaliyetlerinde bulunmasıdır. Hemen yukarnda değindiğimiz gibi, bazı kamu hizmetlerinin, kamu idareleri dışında başka bir tüzel kişiye verilmesi ile o tïzel kişi; kamu kurumu adını almaktadır. Iște bu nedenle, bazı kamu hizmetlerinin tüzel

6 Ozsunay Ergun : «Medeni Hukukumuzda Tüzel Kişiler», 1st. 1969., Sh. 13. 7 Ozsunay Ergun : a.g.e., Sh. 13.

${ }^{8}$ Gözübuiyük, Șeref : «Türkiye'nin Idari Yapısı", Ank. 1969., Sh. 58.

9 Onar, S. Sami : „Idare Hukukunun Umumi Esaslarn», C. 1., Ist. 1966, Sh. 978.

10 Onar, S. Sami : a.g.e. Sh., 1002.

Özsunay Ergun : a.g.e., Sh. 13. 
kişilige sahip meslek teșekküllerine verilmesi ile bu meslek teşekkülleri de kamu kurumu nitelig̈ini kazanmaktadırlar.

Her ne kadar, gördiukleri kamu hizmetị yanị sıra, meslekî teşekküller, surf meslekî faaliyetlerde de bulunuyorlarsa da, özellikle kanunun açıkca kamu kurumu niteliğini verdiği durumlarda bu meslek teşekküllerinin kamu kurumu saylıp saylmayacağı hususunda șüpheye düşmemek getekir kanısmdayız.11-

Kamu kurumu niteliğindeki meslek teșekküllerinin özelliklerini şöylece sıralayabiliriz : Bunlar; kanunla kurulur, o meslek mensuplarını kapsar, meslek mensuplan meslekî faaliyette bulunabilmek için teşekküle katılmak zorundadırlar, teşekkülün organları üyeler arasından ve üyeler tarafından seçilir, seçilmiş organlar idarece yargı mercii kararı olmaksızın süreli veya süresiz görevlerinden uzaklaştırılamaz, bu teșekküllerịn işleyiş ve yönetimleri demokratik esaslara aykurı olamaz.

Kamu kurumu niteliğindeki meslek teşekküllerinin Türk Hukukunda uzun bir geçmişleri vardır. Bu süreç içinde bu teşekküller, giderek daha organize olmuşlar ve 1961 Anayasası ile anayasal güvenceye de kavuşmuşlardır. ${ }^{\text {th }}$

\section{B - Özel Hukuk Tüzet Kișileri :}

Bunlar kaynağını özel hukuktan alan, özel hukuk kanunları ile düzenlenen tüzel kișiler olup, kamu otoritesini kullanma yetkisine sahip değildirler. ${ }^{14}$ Özel hukuk tüzel kişileri, gayelerinin iktisadî bakımdan taşıdı̆̆ özellik itibariyle, kazanç gayesi gỉden tüzel kişiler ve kazanç gayesi gütmeyen tüzel kişiler olmak üzere ikiye ayrilır.

"Onar, S. Sami : ag.e., Sh. 1013.

12 Bu teşekkưllerin hukukî durumlannın idarî tasarruflarla düzenlenip düzenlenemiyeceği hususundă bk.: Duran, Lütfi aldare Alaninin düzenlenmesinde Teşrii ve Tanzimi Tasarruflarm Sinurlann, IHF. Mec. C. XXX., Sh. $471 \mathrm{vd}$.

13 Türk hukukunda kamu kurumu niteliğinde saylan meslek teşekküllexi sunlardır: Barolar ve Türk Barolar Birliği, Ziraat Odalarn ve Ziraat Odalan Birliği, Ticaret Odaları ve Ticaret Odaları Birliği, Tabib Odaları ve Türk Tabibler Birliği, Eczacı Odaları ve Türk Eczaclar Birliži, Mühendis ve Mimar Odalarn ve Türk Mühendis ve Mimar Odaları Birliği, Veteriner Hekimi Odalan ve Veteriner Hekimleri Birliği, Esnaf ve Küçüuk Sanatkâr Derneği, Ihracatçı Birlikleri.

" Ozsunay Ergun: a.g.e., Sh. 13. 
a - Kazanç gayesi güden tüzel kişiler : Bunlara genellikle şirket denilir. Bunlar Ticaret Kanunu hükümlerine tâbidir ki bu ka, nun şirketleri; kollektif, komandit, anonim, limited ve kooperatif türlerine ayırmıştır. Bunların hepsi tiuzel kişiliğge sahiptir. ${ }^{15}$

b - Kazanç gayesi gütmeyen tüzel kişiler : Íktisadî olmayan gayeler o kadar çok ve o kadar çeşitlidir ki, bunları bir madde içine sığdırmanın mümkün olmadığını bilen kanun koyucu Medeni Kanunun 53. maddesinde «Siyasî, dinî, bedî̀, hayrî cemiyetlerle eł̆lence ve idman cemiyetleri ve asıl gayesi iktisadî olmayan diğer cemiyetler......» ifadesini kullanarak, bir derneğin gayesinin neler olabileceğine dair yalnız birkaç örnek vermekle yetinmiştir. ${ }^{16}$

Medeni Kanun iktisadî gaye gütmeyen tüzel kişileri de mahiyetleri itibariyle ikiye ayırmıştır.

aa - Dernekler :

Dernek, iktisadî olmayan yani manevî bir gaye etrafında toplanmış ve birleşmiş olan gerçek kişilerden oluşur. Cemiyetler Kanununum 1, maddesi dernekleri «kazanç paylaștırmaktan başka bir amaçla ikiden ziyade kişinin bilgilerini, faaliyetlerini sürekli bir şekilde birleştirmeleri suretiyle kurulan dernekler ${ }^{*}$ ifadesini kullanarak tarif etmiştir. Bunun yanında derneklerin kuruluşunu dïzenleyen Medeni Kanunun 53. maddesi «asıl gayesi iktisadî olmayan» derneklerden bahseder.

Görüldüğii gibi, derneklerle şirketleri birbirinden ayran kıstas, Medeni Kanunda «iktisadî gaye», Cemiyetler Kanununda ise «kazanç paylaştırma gayesi» olarak belirtilmiștir. Cemiyetler Kanunu Medeni Kanundan daha sonra çıkan bir kanun olduğu ve aynı zamanda da daha özel bir kanun olması itibariyle, sözì geçen kanunun, Medeni Kanundaki iktisadî gaye kıstasını ortadan kaldırmış oIduğu iddia edilebilir veya aynı suretle Cemiyetler Kanununun Medeni Kanundaki iktisadî gaye kavramı ile ne anlaşılması gerektiğini gösterdiği ileri sürülebilir. Kanımızca bu son yorum șekli daha dogrudur. ${ }^{17}$

Kazanç paylaşma iktisadî gayelerden bir tanesidir. Yani iktisadî gaye kavramına nazaran daha dar bir kapsamı vardır. Bu du-

\footnotetext{
15 «Ticaret şirketleri hükmî şahsiyeti haiz olup, şirket mukavelesinde yazilı işletme mevzuunun çevresi içinde kalmak şartıyla büttiin hakları iktisap ve borçları iltizam edebilirler" (TK. Md. 137/I).

16 Velidedeoğlu, H. Velted : a.g.e., Sh. 181.

${ }^{17}$ Akipek Jale : a.g.e., Sh. 242.
} 
rum karşısında kanun koyucunun Medeni Kanundaki iktisadi gaye kavramına geniş bir kapsam vermek istemediği anlaşıllır. ${ }^{18}$

bb - Vakiflar :

Bunlarda esas olarak manevî gayeli olan tüzel kişilerdir. Va. kuf belli bir gayeye tahsis edilmiş mal topluluğudur. Bu çeşit tüzel kişilerin özelliği, hukuk süjesi olarak kabul edilen mal varlığının tüzel kişi dıșındaki bir irade tarafından seçilen gayeye tahsis suretiyle kişilik kazanmasıdır. ${ }^{19}$

Nihayet şunu da belirtmek gerekir ki, iktisadî gayelerle vakıf kurulmasına hukukumuzda bir engel yoktur. Zaten vakıflarnn mahiyeti de iktisadî bir gayeye ulaşmak amacıyla kurulmalarına engel teşkil etmez.

\section{B O L U M}

\section{GENEL OLARAK SENDIKALAR}

\section{1 - Sendikalarn Hukuki Düzenleme İçindeki Yerleri}

\section{A - Tantm :}

1317 Sayılı Kanunla değişik 274 Sayılı Sendikalar Kanununun 1. maddesinin 1. fikrası «Sendika, Federasyon, ve Konfederasyonlar, bu kanuna göre işçi saylanlarm ve işverenlerin müşsterek, iktisadî, sosyal ve kültürel yararların korumak ve geliștirmek için kurulan meslekî teșekküllerdir.», hükmünü koymuştur.

Buna göre sendikalar, her şeyden evvel mesleğin müşterek menfaatlerini temsil ve müdafaa eden $^{2 t}$ ve meslek birliklerine, meslek dayanışmasına imkân veren, çalışan ve çalıștıranların dertlerini ka. mu oyuna anlatmayı sağlamak amacıyla kurulan tüzel kişiliğe sa. hip $^{22}$ meslek teşekkülleridir.

\footnotetext{
18 Akipek Jale : a.g.e., Sh. 243.

19 Doğanay Ümit : a.g.e., Sh. 6.

${ }^{n}$ Akipek Jale : a.g.e., Sh. 239.

2t Saymen, Ferit, Hakkı : "Sendikalar Kanun Tasarısı Hakkında Mütalâa», İşveren, C. 1., Sayı 2., Yıl 1962-1963., Sh. $10 \mathrm{vd}$.

2 "Sendikalar ve Grev, Lokavt Haklar», Türkiye Işçi Sendikaları Konfederasyonu yayın,, Ank. 1964, Konuşan : Muhittin Gürün, Sh. 571.
} 
B - Sendikaların Bir Tüzel Kişi Olarak Hukukî Mahiyeti :

a - Kamu Hukuku Tüzel Kişileri Açısından :

Burada özellikle kamu kurumu niteliğindeki meslek teşekkülleri ile sendikaların hukukî niteliği arasındaki farka değinmek istiyoruz. Doktrinde sendikaların kamu kurumu niteliğindeki meslek teşekkülï sayılıp sayılmayacağı hakkında görüş aymlıkları vardır.

Prof. Dr. Sıddık Sami Onar sendikaları da kamu kurumu niteliğinde meslek teşekküilü olarak kabul etmektedir. Düşünür'e göre «sosyal ve ekonomik hayatın doğurduğu bu teşekkïller tam bir hizmet ademi merkeziyeti teşkilâtı sayılmayabilir. Ancak sendikalar, sosyal haklar, iş düzeni, sermaye gücü ile emek gücü arasında bir denge kurmaları bakımından Devlet ve kamu hukukunu ilgilendiren müesseseler haline gelmiș, klâsik tipten çok farklı olmak ve kamu tüzel kişilerinden ziyade derneklere yanașmakla beraber idare hukukunda da önemli yer almışlardır. Esasen bugün eski kamu kurumu kavramı, konusunu ve kriterlerini kaybetmiş gibidir». ${ }^{23}$

Her ne kadar düşünür, sendikaları da kamu kurumu niteliğinde meslek teşekkülü olarak kabul etmekte ise de, biz bu görüșe katılamıyoruz. Çünkü, 1317 Sayılı Kanunla değişik 274 Sayılı Sendikalar Kanununun 1. maddesi,

«1. Sendika, Federasyon ve Konfederasyonlar, bu kanuna göre işçi sayılanların ve işverenlerin müşterek iktisadî, sosyal ve kültürel yararlarını korumak ve geliştirmek için kurulan meslek teşekkïlleridir.

2. Birinci bentte zikredilen meslekî teșekküllerin kurulması serbest ve ihtiyaridir.",

hükmünü getirmektedir. Görüleceği gibi, kanun koyucu, bu meslekî teşekküllere, kamu kurumu niteliğini vermediği gibi, bunların kurulmasını da meslek mensuplarının isteklerine bırakmıştır. Kanımızca, sendikalar kamu kurumu olsalardı, bunun sonucu olarak bunlara kamu hizmeti yapmak görevi de verileceğinden, kanun koyucu bu meslek teșekküllerinin meydana gelmesini mensuplarının isteğine bırakmazdı. Aksi düșünce, bir kısım kamu hizmetlerinin; kurulmaları şüpheli olan, hukukî güvence altına alınmayan teșekküllere verilmesi gibi desteklenemiyecek bir sonuç doğuracaktır.

23 Onar S. Sami : a.g.e., Sh. 912 vd.; aynı zamanda bk.: T.C. Devlet Teşkilâtı Rehberi., 1968., Sh. 527. 
Kaldı ki, kanunla kamu kurumu niteliği verilmiş bütün meslek teşekküllerine, o meslek mensuplarının üye olmaları zorunlu iken, sendikalar için böyle bir durum söz konusu değildir. ${ }^{24}$

Nihayet, kamu kurumu niteliǧindeki meslek teșekküllerinde organların, üyenin meslekten çıkarlması gibi ferdin meslek bakımından sahip olduğu sübjektif hakkı etkileyen ve bundan ötürü kamu hukuku alanına gireh yetkileri oldưgu halde, sendika organlannin böyle yetkileri yoktur.

Zaten Sendikalar Kanununun diğer kanunlarn uygulanmasıns gösteren 32. maddesi «tş̧i ve Işsveren Sendikaları ......... Medenî Kanunun ve Cemiyetler Kanununun issbu kanuna aykırı olmayan hükümlerine tâbidirler.» diyerek, sendikaların özel hukuk mevzuatı içinde yer aldığını ve bir özel hukuk tüzel kişisi oldư̆unu belirtmiş bulunmaktadır.

\section{b - Ozel Hukuk Tüzel Kişileri Açısından :}

Herşeyden evvel şunu belirtmek gerekir ki, özel hukuk tüzel kișileri tahdidîdir. Yani, ya iktisadî gaye güden tüzel kișiler olarak ya da iktisadî gaye gütmeyen tuizel kişiler olarak kurulurlar. Bunlardan iktisadî gaye güdenleri șirket ve iktisadî gaye gütmeyenleri dernek veya vakıf adını alırlar. Şimdi sendikaların bir özel hukuk tüzel kişisi olarak hukukî mahiyetleri üzerinde duracağzz.

aa - Şirketler Açısından :

Medeni Kanun derneklerle şirketleri birbirinden ayırmak hususunda gayenin iktisadî veya gayn iktisadî olmasından hareket eder. Medeni Kanun, 45. maddesinin 2. fikrasında iktisadî bir gaye takip eden tüzel kişilerin ancak şirket şeklinde kurulabileceğini kabul eder.

Buna göre, özel hukuk tüzel kişilerinin şirket veya dernek mi olduklarını tayinde esas, bu toplulukların takip ettikleri gayedir. ${ }^{25}$

Gaye tüzel kişinin elde etmek istediği son netice, ulaşmak istediği hedeftir.

Derneklerle şirketler arasındaki ayrımın kıstası olan iktisadî gaye kavramı açık bir kavram değildir. Çünkü, bir tüzel kişinin gayesinin iktisadî olup olmadığı her zaman kolaylıkla anlaşılamaz. Ka-

\footnotetext{
${ }^{24}$ bk. 1317 Sayılı Kanunla değişik 274 Saylı Sendikalar Kanunu Md. 5/1.

${ }^{25}$ Akipek Jale : a.g.e., Sh. 240.
} 
bul edilen bir husus *tüzel kişinin gayesinin doğrudan dogruya bir iktisadî faaliyetin icrasına matuf olduğu hallerde $»^{26}$ gayenin iktisadî bir gaye oldugudur.

Kazanç elde etmek ve bu kazancı üyeleri arasında bölïştürerek onların mamelekini çoğaltmak amacında olan tüzel kişiler, iktisadî gayeli tüzel kişiler yani şirketlerdir. ${ }^{n}$

Bunun yanında, iktisadî gayeyi geniş olarak anlayanlara göre, kazanç paylaşmak, iktisadî gayenin tayininde tek ölçü olamaz. Ùyelerine, kazanç paylaştırmaktan başka, diğer ekonomik yararlar să̆lamak amacıyla kurulmuş olan tüezl kişilerin de iktisadî gayeleri olduğu kabul edilmelidir. ${ }^{26}$ Diğer taraftan bazılanna göre, iktisadî gaye kavramını tayin etmek biraz takdirî olmakla beraber, bunu, üyelerinin malvarlığına para ile ölçülebilen maddi bir değer eklenmesi şeklinde anlamalıdur. ${ }^{29}$

Medeni Kanundan sonra çıkan Cemiyetler Kanunu ise dernekleri kazanç paylaşmaktan başka bir amaçla kurulan tüzel kișiler olarak tarif eder ki, bu kanun, Medeni Kanundaki iktisadî gaye kavramı ile ne anlașılması gerekeceğini göstermiştir. Buna göre, «üyelerinin mamelekinde mâli bir faydanın yani menfi veya müspet bir artışın tahakkuku ve bu artışın üyelerin müşterek gayret veya vasıtalarının mahsulüi olması» ${ }^{30}$ kazanç paylaşma gayesini ortaya çlkarir.

Cemiyetler Kanunundaki kazanç paylaştırmak kavramını bu șekilde anlamak gerekir. Bu suretle kazanç paylaştırma Medeni Kanundaki iktisadî gaye kavramı ile az çok aynı anlama da gelmiş olur. ${ }^{31}$

Şu halde, üyelerine her türlü iktisadî yararlar sağlamaya çalışan gayeler değil, fakat sadece onlara mamelekî yararlar sağlayan gayeler kazanç paylaştırma gayesi ve de iktisadî gaye sayılır.

Şirketlerin ayırıcı kıstası olan kazanç paylaștırma kavramını açıkladıktan sonra şimdi de sendikaların, şirket olup olmadıklarıbelirtebiliriz.

${ }^{26}$ Ernst Hirsch : "Ticaret Hukuku Dersleri», Ank. 1948., Sh. 185.

z Akipek Jale : a.g.e., Sh. 241.

28 Akipek Jale : a.g.e., Sh. 242.

* Bilgişin Ali : «Tiçaret Hukuku Prensipleri», 1. Kitap, 1st. 1950, Sh. 9.

30 Arslanl, Halil : «Kollektif ve Komandit Șirketler», Ist. 1956, Sh. 49.

${ }^{31}$ Akipek Jale : a.g.e., Sh. 243. 
Her şeyden evvel sendikaların tüzel kişilik kazanması şirketlerden farklıdır. Sendikaların tüzel kişilik kazanmasında, Sendikalar Kanununun 12. maddesinin 1. fıkrası «...... meslekî teșekkülün tüzüğünü mahallin en büyük mülkiye amirine ...... tevdi ile birlik. te, ... tüzel kişilik...» kazanacağını belirterek, bildirimi yeterli görmüştür. Halbuki şirketlerde tüzel kişilik, şirketin ticaret siciline tescili ile başlar. ${ }^{32}$.

Bunun yanında Sendikalar Kanununun 15. maddesi sendikaların ticaret yapamıyacağını da belirtmis ve aynı maddenin 3. fikrasinda «14. maddenin 1. bendinin (i) fikrası gereğince bu meslekî teşekküllerin kurdukları tesislerin işletilmesinde, - - üyelerin bu tesislerden istifadesi hali hariç — kâr, bu teşekküllerin üyeleri ve mensupları arasında risturn şeklinde de olsa dağıtılamaz.» denilerek, sendikaların kazanç paylaştırma gayesi güdemiyecekleri açı olarak belirtilmiştir.

Kaldı ki 1317 Sayılı Kanunla değişik 274 Sayılı Kanunun, diğer kanunların uygulanmasını gösteren 32. maddesi dahi sendika, federasyon ve konfederasyonların, Medeni Kanun ve Cemiyetler Kanununun işbu Kanuna aykırı olmayan hükümlerine tâbi olduk. ların belirterek, sendikalar hakkında Ticaret Kanununun uygulanması yolunu kapatmıștır.

Nihayet, Sendikalar Kanununun T.B.M.M.'deki tartışmaları s1rasında «... sendikaların kazanç paylaşmak gayesinin bulunmamas1, karakteristik bir hususiyettir, bu vasfiyla sendikalar șirketlerden ayrilır. ......» denmek suretiyle de, sendikaların şirket olmadıkları belirtilmiş ve bu husus Meclis zabıtlarına geçmiștir. ${ }^{33}$

bb - Dernekler Açısından :

Sendikalar, ihtiyarî, yani üyelerinin istekleri ile serbestçe kurulan topluluklardan oldukları için ${ }^{34} 1317$ Sayılı Kanunla değişik 274 Saylı Sendikalar Kanunu ile özel hukuk tüzel kișilerinden ve Medeni Kanunla Cemiyetler Kanununda belirtilen «asil gayesi kazanç paylaştırma olmayan» derneklerdendir. Bilindiği gibi, Medeni Kanunda asıl amacı iktisadî olmayan tüzel kișiler, dernekler ve vakıflar olarak ikiye ayrılmıştır. Sendikalarda da mesleğin ortak çı-

32 Ansay Tư̆rul : «Anonim Șirketler Hukuku», 3. bası., Ank. 1970., Sh. 20.

33 "Sendikalar ve Grev, Lokavt Hakları", a.g.e., Konuşan : Orhan Apaydın., Sh. 643 .

${ }^{34}$ bk. 1317 Sayılı Kanunla değişik 274 Sayılı Sendikalar Kanunu Md. 1/2 
karlarının temsil ve korunmasının esas amaç olması, ${ }^{35}$ bunların asıl gayesi iktisadî olmayan dernekler içinde sayılmasını gerekli kılmasına ve dernek kurma hak ve hürriyeti meslekî teşekkïl kurma hakkını da kapsamasına rağmen, tecrübeler bu alandaki hürriyetin ayrıca düzenlenmesine gerek olduğunu göstermiştir. ${ }^{36}$ Sendika toplulukları lâlettayin dernekler olmayı sosyal ve iktisadî hayatta gerçekten önemli rolleri bulunduğundan, ${ }^{37}$ bunların, 3512 Saylh Cemiyetler Kanununun varlı̆ğna rağmen, belirli nitelikleri göz önünde tutularak, kanun koyucu tarafindan adı geçen Sendikalar Kanunu çıkarılmıştır. ${ }^{38}$ Gerçekten Sendikalar Kanunu incelendiği zaman, bu kanunun yeni bir özel hukuk tüzel kişisi tipi yaratmadığı ve sendikaları dernek olarak kabul ettiği görülür.

Örneğin, sendikalarda da, derneklerde olduğu gibi, Cumhuriyet, Millî, Ulusal ünvanlarının kullanılışı Bakanlar Kurulunun iznine bırakılmış ve Medeni Kanunun 48. maddesinde hâkim olan esaslar çerçevesinde sendika organları ile sendika tüzel kişiliği arasındaki hukukî bağ ve organların organ ve kiși olarak sorumluluğu açıkca belirtilmiştir. Yine derneklerde olduğu gibi, sendikaların da, kurulușundan ve kurucularından idareyi haberdar etmek bakımından konulmuş bir hüküm vardır.

Madem ki sendika bir dernektir, ama öyle bir dernektir ki, özel bir alanda faaliyette bulunacaktır, o halde sendikanin faaliyeti T.C. Anayasasının 29. maddesinde dernek hürriyetine çizilen sinırlarla da smirlanabilir. Bu sımrlar da, kamu dïzeni, genel ahlâk ve adaptir.

\section{2 - Sendikaların Hukukî Düzenleme Dişında «Sosyal Gerçek- lik» teki Yerleri :}

\section{A - Menfaat Grubu, Baskt Grubu Kavramt ve Ayrum :}

Müş̧terek yararlarmı sağlayabilmek için, insanlar çeşitli şekillerde bir araya gelerek gruplar teşkil ederler. Her ne kadar, 1789

35 « Sendikalar ve Grev, Lokavt Haklar», a.g.e., Konuşan : Coskun Krrca., Sh. 571 .

36 Oztürk, Kázım : "Türkiye Cumhuriyeti Anayasası», c. 2, Md. 1-75., Ank. 1966, Sh. 2038., Anayasanın 46. maddesinin gerekçesi.

37 "Sendikalar ve Grev, Lokavt Haklart», a.g.e. Konuşan : Seyfi Öztürk., Sh. 569; Anayasa Mah. Kar. 27/9/1967 E. 1963/336, K. 1967/29 Sayll karan için bk.: RG. 19.10 .1968 .

3a Sunar, K. Salih : "Türk Sendikalar Hukuku», 1. Kitap., Ank. 1955, Sh. 15. 
Fransız thtilali sonrası, ferdiyetçilik görüşünce benimsenmemişse de, kişilerin müsşterek yararlarını daha iyi sağlayabilmeleri gerçeği, çeşitli grubların doğumuna ve giderek bunların sayılarını artmasina sebeb olmuştur.

Ortak yararları bulunan gruplar, menfaat grubu veya baskı grubu olarak görülïirler.

Bazı düşünürler, iki grup arasındaki ayrımı organizasyona sahip olup, olmamakta bulmușlardır. Eğger, müșterek menfaati bulunan insanlardan meydana gelen küme, organize dełgilse, ortaklaşa yararlarının şuurundan uzaksa bir menfaat grubu; aksine, ortaklașa yararlarının şuuruna sahip ve organize ise bir baskı grubudur, demișlerdir."

Ancak, buna karşı çıkan görüşler, ayrımı organizasyonda değil, aksiyonda, davranıs biçiminde bulmuşlardır. Bizimde katıldığımız bu görüş̧e göre, eğer müşsterek yaran olan grup, bu yararlarını sağlamak için siyasal karar merkezlerinden taleplerde bulunur, bu organlar kanalı ile isteklerini sağlamaya çalışırsa, o zaman, baskı grubu olabilir. Aksi halde, bir menfaat grubu söz konusudur. ${ }^{40}$

Ancak, bazan grupların, menfaatlerini sağlayacak davranışlarda bulunmalan, kuvvetli bir organizasyona (organlaşma, işbölümü) ihtiyaç gösterir ki, bu şekildeki topluluklara dernek denilmektedir. Hem baskı, hem menfaat grubu olarak faaliyette bulundukları görülmektedir. Bu organize gruplar, genellikle baskı grubu olarak davranmaktadırlar. Örneğin; sendikalar.

\section{B - Bir Baski Grubu Olarak, Sendikalar :}

Herşeyden önce sendikalar iyi bir organizasyona sahiptir. Ancak, menfaat grubu, baskı grubu ayrımında kabul ettiğimiz kıstasa göre, bunların sadece organize olmalarına bakarak bir değerlendixmede bulunmaya imkân yoktur. Davranışlarını da incelememiz ve siyasal karar merrkezlerinden istekte bulunup bulunmadıklarinı gözlememiz gerekecektir ki, bir yargiya varabilelim.

$\mathrm{Bu}$ nedenle, aşağıda sendikaların bildirilerinden, davranış şekillerinden birkaç örnek alnarak bir sonuca varmaya çalışılacaktur.

\footnotetext{
${ }^{39}$ Aybay Rona : «Bask1 Gruplar1», tHF. Mec., C. XXVII., Say1 1-4., Sh. 281.

40 Zabunoğlu, Yahya : «Baskı Gruplan», Teksir., Ank. 1967., Sh. 38.

Kapanî, Münci : «Kamu Hürriyetleri», Ank. 1970., Sh. 247.
} 
Yapı-Işs Sendakısının 4. Genel Kurulu Çalışma Raporunda «Sosyal Adalet, Kalkınma ve Demokrasinin yaratıcı ve yürütücü gücüne içten bağlı olan olan Türk işçileri kalkınmanm demokratik düzen içinde plânlama ile mümküin olabileceł̧ini bilmekte, ancak plânın başrısının temel reformların gerçekleşmesine bağlı bulunduğu inancını da korumaktadırlar» denilmekte ve toprak reformuna ilişkin görüşleri de «arazinin haksız dağılışı, toprak reformunun lüzumunu ortaya koymaktadır. Reform yapılmadan, toprak daha dengeli dağıtılmadan tarımda kalkınma bahis konusu olamaz» șeklinde açıklanmaktadır." Yine aynı Genel Kurul Raporunda "bugünkü durumu ile dış ticaretimiz kamu yararına çalışmayan ve kalkınmamiza set çeken bir durumdadır. Kamu yararına olmayan bir serbest ticaret görüşü de Anayasaya aykırıdır. Yapılacak tek şey, dış ticaretin devletleştirilmesidir» denilmektedir. ${ }^{42}$

Aynı şekilde Türk-Iş tarafından 1968 yılında yayınlanan $7 . \mathrm{Ge}-$ nel Kurul Raporunda da, Türk Isş̧i Hareketinin, yıllardır, demokratik baskı grubu hüviyetiyle görüşlerinin topluma mal edilmesine çalışılmakta olduğu ve Türk İşçi Hareketinin bu çabasının «yurt ve ișçi sorunlarına iliş̧kin» işçi görüşịi olarak ilân edilen «23 ilke» de ifadesini bulduğu ileri sürülmektedir. Bu 23 ilkeden önemli bir kaç tanesi șunlardır :

«Türk-İs Anayasanın sosyal ve iktisadî haklar ve ödev. ler bölümünde yer alan hükümlerin mümkün mertebe kısa zamanda tam olarak uygulanması, Anayasa hükümlerinin yerine getirilmesi ve Anayasada öngörülen bütün hususların işler duruma getirilmesini gerekli sayar. Türk-Iş bu hususun yerine getirilmesi için bütün gücüyle çałş̧mayı, iktidar ve muhalefet partilerini bu yolda çalışmaya yöneltme için etki gücünü kulanmayı ödev bilir.»

"Tarım işçilerini kısa zamanda Tarım Iș Kanununa kavuşturmak,.........Türk-Iş'in başlıca görevleri arasındadir.»

"Mümkün olduğu kadar, bütün işçilerin Iş Kanunu kapsamına alınmaları Türk-Iș'ce sağlanacaktır.»

"Topraksız, az topraklı veya dar gelirli köylünün yeterli toprağa ve verimli tarım işletmeciliğine kavușmasını

4 Yapı-1s 4. Genel Kurulunun Çalışma Raporu., Izmir 1969., Sh, 30 vd.

- Yapı-tş 4. Genel Kurulunun Çalıșma Raporu., Izmir 1969., Sh. 40. 
sağlayıc1,.........toprak ve tarım reformu yaplmasını ve bunun biran önce gerçekleştirilmesi için siyasî partiler üzerinde bütün etkisini kullanmayı Türk-Iș başlica görev sayarss. ${ }^{43}$

Yine Türk-İş̧in yayınladığı sözü geçen raporunda eğitim reformu gereğine değinilmiş ve "Türkiye'nin gelișmiş batı ülkeleriyle arasındaki farkı kapayabilmesi için eğitimde, eğitim teşkilâtında ihtilâl yapması gerektiği» belirtilmiş, ${ }^{44}$ bütün bunların yanında, o zamanki iktidar tarafından hazırlanan «Anayasa Nizamını Koruma Kanun'u» tasarısı hakkındaki görüşleri de şu şekilde açıklanmıștır :

«Hükümet edenlerin sosyal ve ekonomik tedbirler yerine, daima özgürlükleri kısıtlamayı tercih eğiliminde bulunmaları yüzünden aşırı uçlar genişleme ortamı bulabilmişlerdir.

Nitekim, son olarak,.......konuyu tamamen ters bir aç̧dan ele alarak, "Anayasa Nizamını Koruma Tasarısı" gibi, duișünülmesi dahi imkânsız sayılabilecek tedbirler alma yolunu tercih etmişlerdir.

Türk İş̧̧i Hareketi Anayasa Nizamını Koruma adı altında demokrasiyi zedeleyerek, hakları ve hürriyetleri kısıtlayıcı davranışların daima karşısında olacaktırn.45

Sendikalar, görüldüğü gibi, zaman zaman siyasal iktidar üzerine baskı yaparak, isteklerinin gerçekleşmesini denemekte, bu yolda çaba göstermektedirler. Bu nedenle, sendikalarn siyasal hayatrmızda zaman zaman bir baskı grubu olarak görmekteyiz demek, sanırız yanlış bir ifade olmayacaktır.

\section{S O N U ç}

Bu kısa çalıșmamızda göstermektedir ki, sendikalar dünya tarihinde uzun bir geçmișe sahip olmalarına rağmen, Türk Devlet hayatında, özellikle 1961 Anayasasında anayasal güvence altına alın. diktan sonra, etkin rolleri olmuştur.

${ }^{43}$ Türk-\$s 7. Genel Kurul Çalışma Raporu., Ankara 1968 Sh, 30 vd.

44 Türk-Iş 7. Genel Kurul Çalıșma Raporu., Ankara 1968., Sh. 62 vd.

45 Türk-1s 8. Genel Kurul Çalışma Raporu., Erzurum 1970., Sh. 80 vd. 
Türk siyasal hayatında devletin gerek hukukî yapısı içinde dernek olarak yer almışlar, gerekse de devletin hukukî yapısıı dışında, siyasal iktidar üzerinde bir baskı grubu olarak etkili rol oynamıslardır.

Şurası unutulmamalıdır ki, organize olmuş sendikalar hem bünyelerindekilerin ortak çıar ve düșüncelerini temsil etmekte, savunmakta; hem de kamu oyunun biçimlenmesine etkide bulunmak. tadirlar. 


\section{KAYNAKLAR}

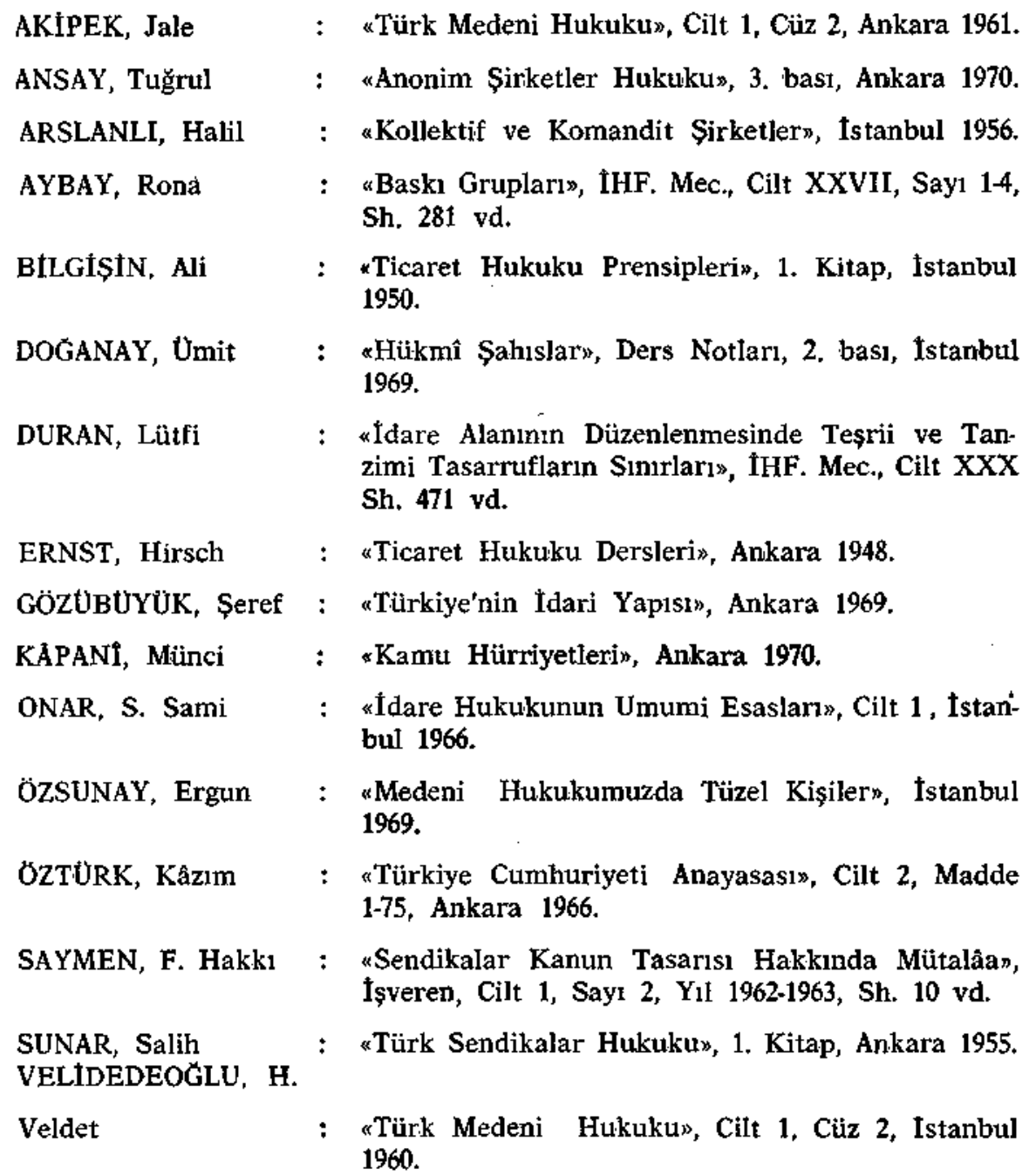

ZABUNOĞLU, Yahya : "Baskı Gruplan», Teksir. Ankara 1967. 